\title{
Adsorption Properties of Bentonite with In Situ Immobilized Polyaniline Towards Anionic Forms of Cr(VI), Mo(VI), W(VI), V(V)
}

\author{
Kateryna RYABCHENKO ${ }^{1}{ }^{*}$, Elina YANOVSKA ${ }^{1}$, Mariya MELNYK ${ }^{1}$, \\ Dariusz STERNIK ${ }^{2}$, Olga KYCHKIRUK ${ }^{3}$, Valentun TERTYKH ${ }^{4}$
}

\author{
${ }^{1}$ Chemistry Faculty, Kyiv National Taras Shevchenko University, 64 Volodymyrska Str., 01033 Kyiv, Ukraine \\ ${ }^{2}$ Maria Curie-Skłodowska University, pl. Maria Curie-Skłodowskiej 3, 20-031 Lublin, Poland \\ ${ }^{3}$ Department of Sciences, Ivan Franko Zhytomyr State University, 40 Velyka Berdychivska Str., 10008 Zhytomyr, Ukraine \\ ${ }^{4}$ Chuiko Institute of Surface Chemistry of the National Academy of Sciences of Ukraine, 17 General Naumov Str., 03164 \\ Kyiv, Ukraine \\ cross $^{\text {ref }}$ http://dx.doi.org/10.5755/j01.ms.22.2.6976
}

Received 18 April 2014; accepted 25 January 2015

\begin{abstract}
A new composite material bentonite-PANI was synthesized by in situ immobilization of polyaniline (PANI) on the surface of natural mineral bentonite. It was established as a result of the modification of bentonite a surface area and an interlayer distance of mineral decrease and particles of bentonite transformed of irregular shape with different porosity on irregularly shaped particles of smaller size. It has been found that the total $\mathrm{Cr}(\mathrm{VI})$ ions extraction took place under the acid conditions $(\mathrm{pH}=1-2)$ and $\mathrm{W}(\mathrm{VI})$ ions have been well adsorbed in the $\mathrm{pH}$ range from 1 to 8 by the composite bentonite-PANI unlike the initial mineral. Whereas adsorption of oxo anions of $\mathrm{V}(\mathrm{V})$ and $\mathrm{Mo}(\mathrm{VI})$ made up some $50 \%$. It is proved that the in situ immobilization of bentonite by polyaniline leads to increasing the value of adsorption capacity towards the investigated ions compared with the initial mineral. It was established that the adsorption properties of the synthesized composite with respect to the studied oxo ions were worse than the adsorption properties of composite vermiculite-PANI, similar to the composite Sokyryntsyy clinoptilolite-PANI and better than composites of polyaniline with Podilskyy saponite and Karelian shungite.

Keywords: bentonite, polyaniline, in situ immobilization, composite, adsorption, W-, Mo-, V- and Cr-containing ions.
\end{abstract}

\section{INTRODUCTION}

One of the most dangerous sources of pollution of the environment is an industrial wastewater, the main components of which are heavy metals. In particular, wastewater of chemical and metallurgical industries contains large amounts of toxic metal ions such as chromium, vanadium, tungsten and molybdenum. The most dangerous of these metals is $\mathrm{Cr}(\mathrm{VI})$, which is a carcinogen. Other studied metal ions are less toxic, but excessive their amount has a negative impact on the environment, in particular, inhibits plant growth [1].

The principal methods of cleaning of wastewater from the heavy metal ions are: neutralization by acids or alkalis; application of coagulants and flocculants; using of microbicides and other reagents with subsequent removal of sediment. The disadvantages of these methods are: insufficient degree of purification, salinization and additional pollution of wastewater resulting from the use of toxic reagents, the formation of large amount of sediments, dependence of removal of metal ions on temperature, impurities, etc. [2].

Alternative methods of water purification from chromium ions are the adsorption [3], electrochemical deposition [4], reverse osmosis, membrane filtration [5], which include converting $\mathrm{Cr}(\mathrm{VI})$ to $\mathrm{Cr}$ (III) followed by precipitation by adjusting the $\mathrm{pH}$. Removal of tungsten,

\footnotetext{
* Corresponding author. Tel.: +38044 4518321.

E-mail address: katya-ryabchenko@yandex.ru (K. Ryabchenko)
}

molybdenum and vanadium by alternative methods almost has not been studied.

In this sense, the use of composites based on nitrogen-containing polymers (polyionenes [6-7], polyhexamethylene guanidine [8] and their derivatives [9], polyaniline [10] that are characterized by high adsorption capacity towards oxo ions $\mathrm{Cr}(\mathrm{VI}), \mathrm{Mo}(\mathrm{VI}), \mathrm{W}(\mathrm{VI})$ and $\mathrm{V}(\mathrm{V})$ proved to be promising. Research conducted in the last decades has shown that the attention of researchers has increased towards natural materials in situ immobilized by polyaniline as nanocomposites with interesting structure and properties, which cause a wide range of practical applications. In particular, our studies [11-14] were found that polyaniline in situ immobilized on natural minerals of different chemical nature, such as saponite, shungite, clinoptilolite and vermiculite had a high adsorption capacity towards oxo ions $\mathrm{Cr}(\mathrm{VI}), \mathrm{Mo}(\mathrm{VI}), \mathrm{W}(\mathrm{VI}), \mathrm{V}(\mathrm{V})$ and $\mathrm{P}(\mathrm{V})$.

Bentonite is a natural aluminum silicate, the main component of its composition is montmorillonite with general formula $\left.(\mathrm{Na}, \mathrm{Ca})_{0,3}(\mathrm{Al}, \mathrm{Mg})_{2}\left[\mathrm{Si}_{4} \mathrm{O}_{10}\right](\mathrm{OH})_{2} \cdot \mathrm{nH}_{2} \mathrm{O}\right)$. The largest deposits of bentonite are located in the USA, Canada, UK, Russia, Armenia, Ukraine. Thanks to its good adsorption properties bentonite is widely used for cleaning products of oil refining, coke, food, mining, steel and ceramic industries, foundries, medicine, pharmacology, agriculture [15].

In $[16-18]$ the adsorption activity of bentonite composites towards Th(IV) and dyes was studied, but the adsorption activity on composites bentonite immobilizated by polyaniline towards $\mathrm{Cr}(\mathrm{VI}), \mathrm{Mo}(\mathrm{VI}), \mathrm{W}(\mathrm{VI})$ and $\mathrm{V}(\mathrm{V})$ 
has not been studied yet and, therefore, is the objective of our investigation.

With this mind, the main attention was paid to the investigation of adsorption peculiarities of bentonite with in situ immobilized polyaniline towards oxo anion forms of $d$-metals of $\mathrm{V}$ and VI groups of the Periodic table and the study of regeneration degree of chromium, tungsten, molybdenum and vanadium compounds adsorbed on the composite surface.

\section{EXPERIMENTAL DETAILS}

Polyaniline was immobilized on bentonite (production Sigma Aldrich company) via oxidative polymerization of aniline within a day similar to [13] according to the Fig. 1:

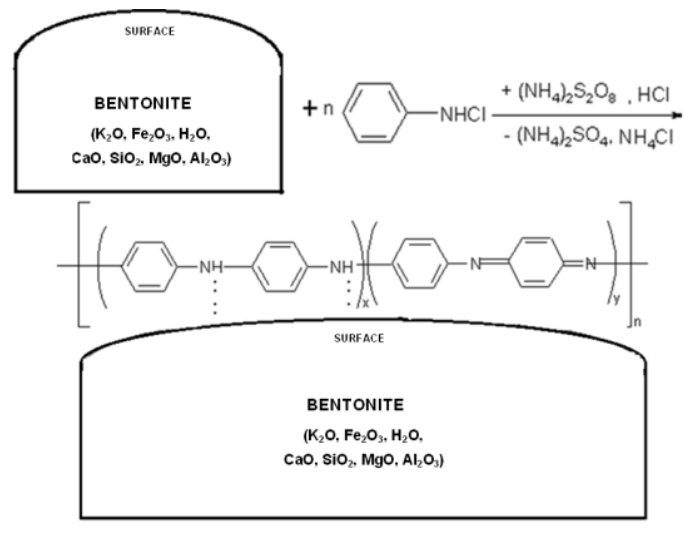

Fig. 1. Synthesis of composite bentonite-PANI

According to [19] referred under these conditions polyaniline can be bound to the surface of the pine sawdust in the form of emeraldine salt (ES). Syntheses of composite controlled by IR spectroscopy and diffuse reflectance electron spectroscopy (DRES). The IR spectra were registered by using a spectrophotometer Nexus 470 with Fourier transformation. The DRES spectra were registered by using the Specord-40 spectrometer (Germany).

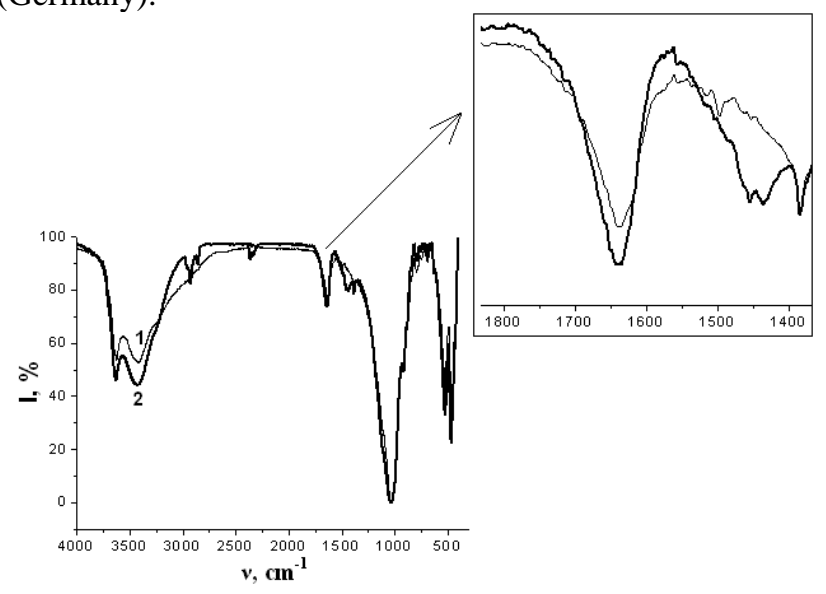

Fig. 2. IR spectra of the initial bentonite (curve 1) and the composite bentonite-PANI (curve 2)

In the IR spectra of the initial bentonite and composite observed a broad intense absorption band in the region of $3300-3650 \mathrm{~cm}^{-1}$ with maximum at 3425 and $3630 \mathrm{~cm}^{-1}$, corresponding to the stretching vibrations of $\mathrm{OH}$-groups and adsorbed water. The broadening of these bands for the composite compared to the initial bentonite caused stretching vibrations of NH-groups of polyaniline [20]. In the IR spectrum of the modified bentonite at 2925 and $2865 \mathrm{~cm}^{-1}$ are low-intensity absorption bands corresponding to the stretching vibration band of $\mathrm{C}-\mathrm{H}-$ bonds benzene ring of polyaniline, which are absent in the spectrum of the initial bentonite.

At $1639 \mathrm{~cm}^{-1}$ in the IR spectrum of the initial bentonite is intense band, which corresponds to the deformation vibrations of adsorbed water in the mineral. A slight increase of intensity of this band in the spectrum of the composite indicates the presence of stretching vibration of $\mathrm{C}=\mathrm{C}$ and $\mathrm{C}=\mathrm{N}$-bonds of polyaniline molecules. Unlike the spectrum of the initial bentonite, in the spectrum of the composite band appear deformation vibrations of $\mathrm{C}-\mathrm{H}$ bonds benzene ring at 1453 and $1435 \mathrm{~cm}^{-1}$. Peaks below $1300 \mathrm{~cm}^{-1}$ correspond deformation and stretching vibrations, which are typical for bentonite $[21,22]$.

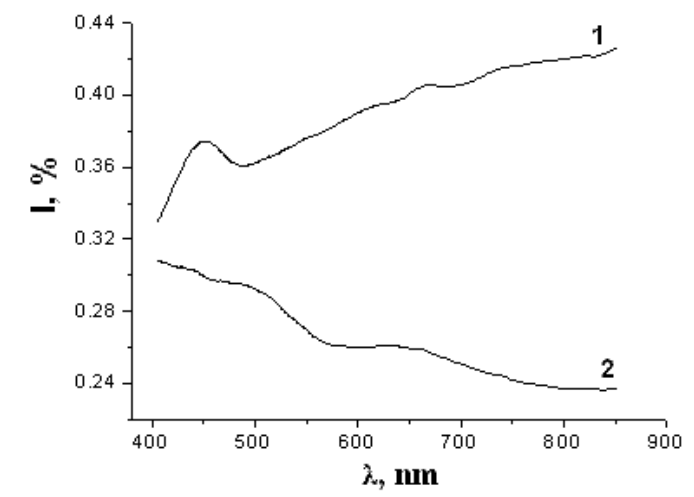

Fig. 3. DRES spectra of the initial bentonite (curve 1) and composite bentonite-PANI (curve 2)

DRES of the composite (Fig. 3, curve 2) has two major bands, the first one being at $\lambda=500 \mathrm{~nm}$ due to $\pi-\pi^{*}$ transition in the restricted area, and the second one at $\lambda=670 \mathrm{~nm}$, which corresponds to the formation of charge carriers of the polaron type the conductive polymers conductive polymers polaron type of charge carriers [23]. In the spectrum of the composite there are inflections that are characteristic of polyaniline but they are absent in the spectrum of the unmodified bentonite (Fig. 3, curve 1).

The comparison of the obtained DRES with the literature [19] allows to speaking that polyaniline forms on the surface of bentonite as emeraldine salt.

The thermogravimetric analysis was performed using thermogravimetric analyzer Q-1500 (MOM, Hungary) at $15-1000{ }^{\circ} \mathrm{C}$. It was showed that the synthesized composite had $22.15 \%$ of polyaniline, which corresponds to its concentration $23.17 \mathrm{mg} / \mathrm{g}$ of bentonite.

\section{RESULTS AND DISCUSSION}

The crystal lattice of bentonite is composed of three layers that form the package. The package (2:1) has two layers of silicate tetrahedron $\left(\mathrm{SiO}_{4}{ }^{2-}\right)$, which return to the each other by tops, between which there is octahedral layer, which consists of aluminum ions. The bonds between packages are weak, and distance between packages is big so molecules of water and ions can infiltrate there. The feature of crystalline structure of bentonite ensures the presence on the surface ion exchange 
cations, which have an influence on physical and chemical properties of the mineral. The isomorphic substitution of $\mathrm{Al}^{3+}$ for $\mathrm{Si}^{4+}$ in the tetrahedral layer and $\mathrm{Mg}^{2+}$ or $\mathrm{Fe}^{2+}$ for $\mathrm{Al}^{3+}$ in the octahedral layers leads to a negative surface charge of bentonite [24]. The chemical composition of the initial bentonite and the modified composite was determined by energy dispersive X-ray spectroscopy (EDX).

Table 1. The elemental composition of bentonite before and after modification

\begin{tabular}{|c|c|c|}
\hline \multirow{2}{*}{ Element } & \multicolumn{2}{|c|}{$\begin{array}{c}\text { The elemental composition of bentonite } \\
\text { before and after modification, \% }\end{array}$} \\
\cline { 2 - 3 } & Before & After \\
\hline $\mathrm{C}$ & 0.73 & 1.62 \\
\hline $\mathrm{H}$ & 1.29 & 1.56 \\
\hline $\mathrm{N}$ & 0.17 & 0.30 \\
\hline $\mathrm{O}$ & 38.41 & 37.01 \\
\hline $\mathrm{Na}$ & 0.08 & 0.12 \\
\hline $\mathrm{Mg}$ & 2.26 & 1.58 \\
\hline $\mathrm{Al}$ & 11.08 & 10.65 \\
\hline $\mathrm{Si}$ & 27.23 & 26.45 \\
\hline $\mathrm{Cl}$ & 0.03 & 0.28 \\
\hline $\mathrm{Pd}$ & 0.46 & 0.49 \\
\hline $\mathrm{K}$ & 1.40 & 1.74 \\
\hline $\mathrm{Ca}$ & 1.80 & - \\
\hline $\mathrm{Ti}$ & 0.26 & 0.27 \\
\hline $\mathrm{Fe}$ & 5.95 & 5.95 \\
\hline
\end{tabular}

The comparison of the data Table 1 indicates a successful intercalation of polyaniline into bentonite and removal of ions $\mathrm{Mg}^{2+}$ and $\mathrm{Ca}^{2+}$ from the sample as a result of the modification.

The modification of bentonite by polyaniline leads to changes in the structural and energetic heterogeneity of the composite, which were identified by means of isotherm adsorption/desorption of nitrogen for the initial mineral and the composite bentonite-PANI (Fig. 4, curves 1 and 2, respectively). Measurements were performed using "ASAP $2420 \mathrm{V1.01"} \mathrm{(Micromeritics,} \mathrm{USA)} \mathrm{at} 77 \mathrm{~K}$. Before measurement samples were outgassed at $60{ }^{\circ} \mathrm{C}$.

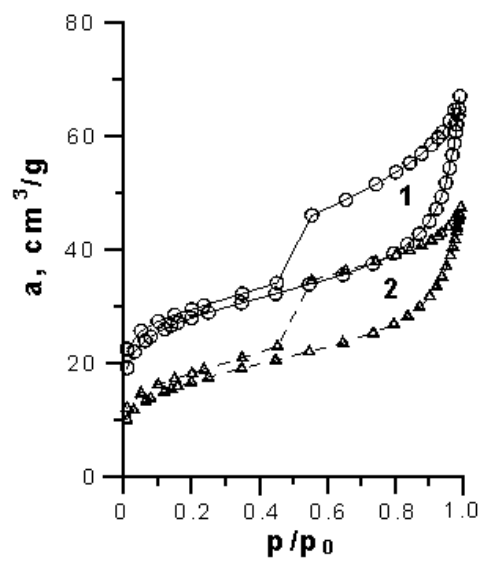

Fig. 4. Adsorption-desorption isotherms of nitrogen for the initial bentonite (curve 1) and the composite bentonite-PANI (curve 2)

The forms of isotherms for the initial bentonite and the synthesized composite are very similar, that indicate a weak influence of polyaniline molecules on the properties of the mineral. However, studies by BET method have shown a change pore diameter of $3.9 \mathrm{~nm}$ for the initial bentonite to $4.6 \mathrm{~nm}$ for the modified polyaniline. Also, from Fig. 4 it can be concluded that the immobilization occurs at the location of polyaniline molecules in both interlayer and interparticle spaces in the bentonite [25]. Using the BET method the surface area were calculated for the initial bentonite and the composite bentonite-PANI, which was 99 and $59 \mathrm{~m}^{2} / \mathrm{g}$ respectively.

For better illustrations of porous structure of the samples were constructed diagrams pore size distribution calculated using the BET method (Fig. 5) [16]. For both samples in Fig. 5 present one narrow symmetrical peak with a maximum at $4 \mathrm{~nm}$.

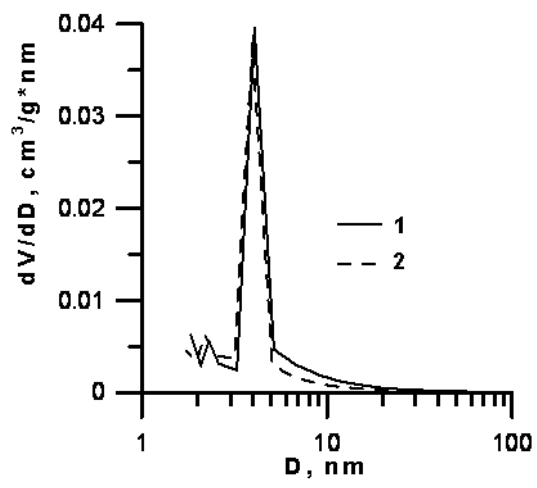

Fig. 5. Pore size distribution curves for the initial bentonite (curve 1) and the composite bentonite-PANI (curve 2)

The X-ray diffraction (XRD) powder patterns were recorded on an Empyrean PANalytical diffractometer (the Netherlands) using Ni filter and an Pixel linear detector ( $\mathrm{CuK} \alpha$ radiation). The data were collected at $298 \mathrm{~K}$ in the angular range $4-50^{\circ}(2 \theta)$ with steps of $0.025^{\circ}$. XRD patterns of the initial (curve 1) and the modified bentonite (curve 2) are presented in Fig. 6.

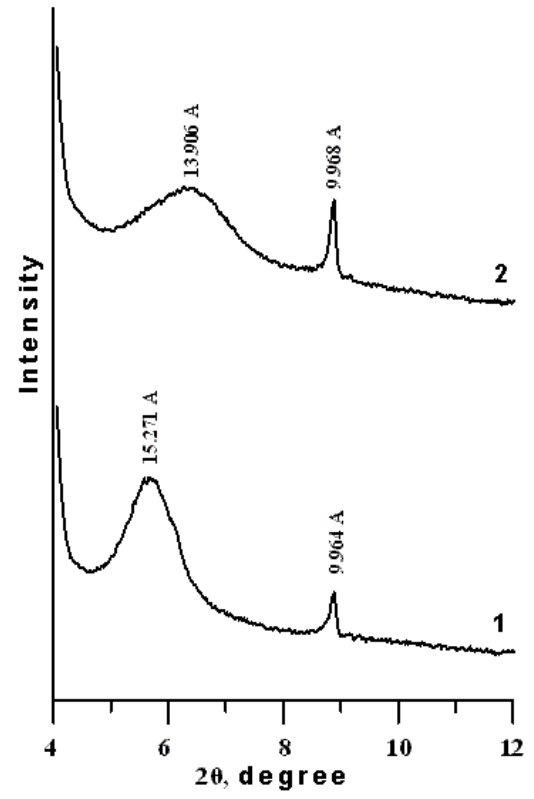

Fig. 6. XRD patterns of the initial bentonite (curve 1) and the composite bentonite-PANI (curve 2)

As Fig. 6 shows, the modification decreases interlayer distance of $1.527 \mathrm{~nm}$ for the initial mineral to $1.39 \mathrm{~nm}$ for the modified composite. These changes indicate that the intercalation of polyaniline occurred in interlayer space of 
bentonite. As a result of the modification, the color of the mineral turned from light brown to dark-green, which also indicate to the consolidation of polyaniline on the surface of bentonite. Similar changes were observed in the case of similar nanocomposites based polyppyrole [27] and vermiculite [13].

Isomorphic substitution of $\mathrm{Al}^{3+}$ for $\mathrm{Si}^{4+}$ in the tetrahedral layer and $\mathrm{Mg}^{2+}$ or $\mathrm{Fe}^{2+}$ for $\mathrm{Al}^{3+}$ in the octahedral layers leads to a negative surface charge of bentonite. The positively charged polyaniline has a high affinity to the negatively charged surface of bentonite so polyaniline immobilized on the mineral surface mainly fixes by electrostatic forces forming a homogeneous polymer layer. To confirm this hypothesis were obtained SEM photographs mineral surface before and after modification by polyaniline (Fig. 7). Scanning electron microscopy SEM were conducted on "Quanta 3D FEG" (Quanta, Germany) operating at a voltage of $30.0 \mathrm{kV}$.

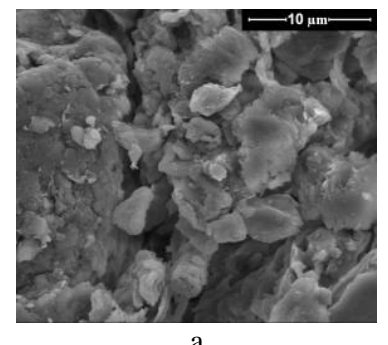

a

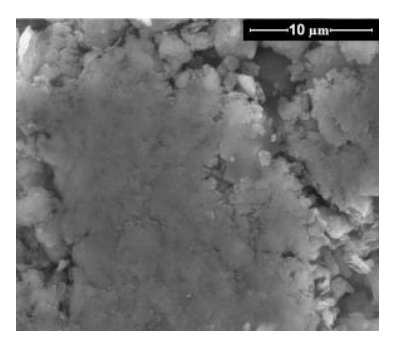

b
Fig. 7. Scanning electron spectroscopy (SEM) (magnification $\mathrm{x} 5000)$ of $\mathrm{a}-$ the initial bentonite; $\mathrm{b}$-the composite bentonite-PANI

As it follows from Fig. 7, the initial bentonite is composed of irregularly shaped aggregates of different porosity, while bentonite modified by polyaniline contains a small number of homogeneous particles of smaller size.

The adsorption properties of bentonite with in situ immobilized polyaniline with respect to anionic forms of $\mathrm{Cr}(\mathrm{VI}), \mathrm{Mo}(\mathrm{VI}), \mathrm{W}(\mathrm{VI}), \mathrm{V}(\mathrm{V})$ and $\mathrm{P}(\mathrm{V})$ were studied in the static mode. The samples of the adsorbent (weight 0.1 g) were brought in to contact with $25 \mathrm{ml}$ of solutions of different concentrations, prepared from the following salts: $\left(\mathrm{NH}_{4}\right)_{2} \mathrm{MoO}_{4},\left(\mathrm{NH}_{4}\right)_{2} \mathrm{CrO}_{4}, \mathrm{Na}_{2} \mathrm{WO}_{4} \cdot 2 \mathrm{H}_{2} \mathrm{O}, \mathrm{NH}_{4} \mathrm{VO}_{3}$.

Photometric studies were performed by using a spectrophotometer SF-46 (LOMO, Russia) with square cuvettes (optical path length $l=1 \mathrm{~cm}$ ). Equilibrium concentrations of anions in the resulting solution were measured according to the following methods.

Spectrophotometric determination of molybdenum [28]. The required volume of the equilibrium solution of $\left(\mathrm{NH}_{4}\right)_{2} \mathrm{MoO}_{4}(0.1 ; 0.2 ; 0.4 ; 0.6 ; 0.8 ; 1.0 \mathrm{ml})$ with a concentration of $100 \mu \mathrm{g} \mathrm{Mo} / \mathrm{ml}$ was placed in a $25 \mathrm{ml}$ volumetric flask, $2 \mathrm{ml}$ of $\mathrm{H}_{2} \mathrm{SO}_{4}(1: 1), 2 \mathrm{ml}$ of $10 \%$ ascorbic acid and $1 \mathrm{ml}$ of $25 \% \mathrm{KSCN}$ were added and diluted to the mark with distilled water. The solution was thoroughly mixed and the optical density at $\lambda=470 \mathrm{~nm}$ was measured. Distilled water was used as a reference solution.

Spectrophotometric determination of tungsten [29]. The required volume of the equilibrium solution of 0.017 $\mathrm{M} \mathrm{Na}_{2} \mathrm{WO}_{4}(0.1 ; 0.2 ; 0.3 ; 0.4 ; 0.5 ; 0.6 \mathrm{ml})$ was placed in a $25 \mathrm{ml}$ volumetric flask, $1.6 \mathrm{ml}\left(\mathrm{NH}_{4}\right)_{2} \mathrm{MoO}_{4}(1 \mathrm{mg} / \mathrm{ml})$, $2.5 \mathrm{ml}$ of $\mathrm{H}_{2} \mathrm{SO}_{4}(2 \mathrm{M})$, and $1 \mathrm{ml}$ of $0.2 \%$ solution of
$\mathrm{SnCl}_{2}$ were added and diluted to the mark with distilled water. The solution was thoroughly mixed and the optical density at $\lambda=610 \mathrm{~nm}$ was measured. Distilled water was used as a reference solution.

Spectrophotometric determination of chromium [28]. The required volume of the equilibrium of $10^{-4} \mathrm{M}$ solution of $\left(\mathrm{NH}_{4}\right)_{2} \mathrm{Cr}_{2} \mathrm{O}_{7}(0.1 ; 0.4 ; 0.7 ; 1.0 ; 1.5 ; 2.0 \mathrm{ml})$ was placed in a $25 \mathrm{ml}$ volumetric flask, $1.6 \mathrm{ml}$ of $\mathrm{H}_{2} \mathrm{SO}_{4}$ (1:10), and $1 \mathrm{ml}$ of $0.1 \%$ 1,5-diphenylcarbazide in ethanol were added and diluted to the mark with distilled water. The solution was thoroughly mixed and the optical density at $\lambda=540 \mathrm{~nm}$ was measured. Distilled water was used as a reference solution.

Spectrophotometric determination of vanadium [30]. The required volume of the equilibrium solution $\mathrm{NH}_{4} \mathrm{VO}_{3}$ containing $1 \mathrm{mg} \mathrm{V} / \mathrm{ml}(0.2 ; 0.4 ; 0.6 ; 0.8 ; 1.0 ; 2.0$; $5.0 \mathrm{ml}$ ) was placed in a $25 \mathrm{ml}$ volumetric flask, $1 \mathrm{ml} \mathrm{H}_{2} \mathrm{O}_{2}$ (3\%) was added and diluted to the mark with $2 \mathrm{~N}$ solution of $\mathrm{H}_{2} \mathrm{SO}_{4}$. The solution was thoroughly mixed and the optical density at $\lambda=490 \mathrm{~nm}$ was measured. Distilled water was used as a reference solution.

The degree of adsorption $(R, \%)$ was calculated according to $[11-13]$ :

$R=\left(m_{\text {ads }} / m_{o}\right) \cdot 100=\left(m_{o}-m\right) / m_{o} \cdot 100$,

where $m_{\mathrm{o}}$ is the mass of a metal in the initial solution, $m_{\mathrm{ads}}$ is the mass of the adsorbed metal, $m$ is the mass of the metal in the equilibrium solution after adsorption, which is calculated as $m=C \cdot V$, where $C$ is the equilibrium concentration of a metal and $V$-volume of the equilibrium solution.

The value of acidity of working solutions during adsorption fixed by the addition of standard buffer solutions at a ratio of 1:5 $(5 \mathrm{ml}$ per $25 \mathrm{ml}$ the working solution). Dependences of the adsorption degree for each of the anions investigated on the acidity of the medium are presented in Table 2.

Table 2. Dependence of the degree of adsorption of the investigated anions regardless the acidity [28-30]

\begin{tabular}{|c|c|c|c|c|}
\hline \multirow{3}{*}{$\begin{array}{l}\text { The degree of } \\
\text { adsorption, \% }\end{array}$} & \multicolumn{4}{|c|}{ Ion } \\
\hline & $\mathrm{W}(\mathrm{VI})$ & $\overline{M o(V I)}$ & $\mathrm{Cr}(\mathrm{VI})$ & $\mathrm{V}(\mathrm{V})$ \\
\hline & 99.99 & 49.32 & 99.99 & 49.40 \\
\hline $\mathrm{pH}$ & $1-9.2$ & $\begin{array}{c}\text { Distilled } \\
\text { water }\end{array}$ & 1.7 & 8.0 \\
\hline $\begin{array}{l}\text { Form of } \\
\text { existence } \\
\text { metal in } \\
\text { solution }\end{array}$ & $\begin{array}{l}\mathrm{WO}_{2}{ }^{2+} \\
(\mathrm{pH}=1) \\
{\left[\mathrm{W}_{6} \mathrm{O}_{21}\right]^{6-}} \\
{\left[\mathrm{W}_{7} \mathrm{O}_{24}\right]^{6-}} \\
(\mathrm{pH}=1.7) \\
{\left[\mathrm{H}_{2} \mathrm{~W}_{12} \mathrm{O}_{40}\right]} \\
6-(\mathrm{pH}=4) \\
{\left[\mathrm{HW}_{6} \mathrm{O}_{21}\right]^{5-}} \\
\left(\mathrm{pH}^{5-} 6.9\right) \\
\mathrm{WO}_{4}{ }^{2-} \\
\left(\mathrm{pH}^{2-} 7\right)\end{array}$ & $\mathrm{MoO}_{4}{ }^{2-}$ & $\mathrm{Cr}_{2} \mathrm{O}_{7}{ }^{2-}$ & $\mathrm{HVO}_{4}{ }^{2-}$ \\
\hline
\end{tabular}

As this table shows, the total chromium extraction took place at $\mathrm{pH} 1.7$ (oxalate buffer) in the form of dichromate ions $\left(\mathrm{Cr}_{2} \mathrm{O}_{7}{ }^{2-}\right)$ on the bentonite immobilized by polyaniline. The comparison of data with previous obtained results [11-13] shows that the optimal value of acidity removal of anions $\mathrm{Cr}(\mathrm{VI})$ by composite bentonitePANI coincide with value of acidity removal for other 
natural minerals modified by polyaniline. It may be indirect evidence that the adsorption of dichromate ions occurs largely due to the interaction of the functional groups by immobilized polyaniline.

Oxo anions W(VI) are quantitatively adsorbed throughout all the investigated $\mathrm{pH}$ range.

As follows from Table 2, maximum oxo anions Mo(VI) removal took place approximately $50 \%$ under neutral media as molybdate ions.

The total V(V) ions extraction by composite bentonitePANI was observed. Maximum oxo anions $\mathrm{V}(\mathrm{V})$ removal took place under alkaline media at $\mathrm{pH}=8$ as $\mathrm{HVO}_{4}{ }^{2-}$ ions [29]. Adsorption of ions occurs by ion exchange mechanism according to the Fig. 8:
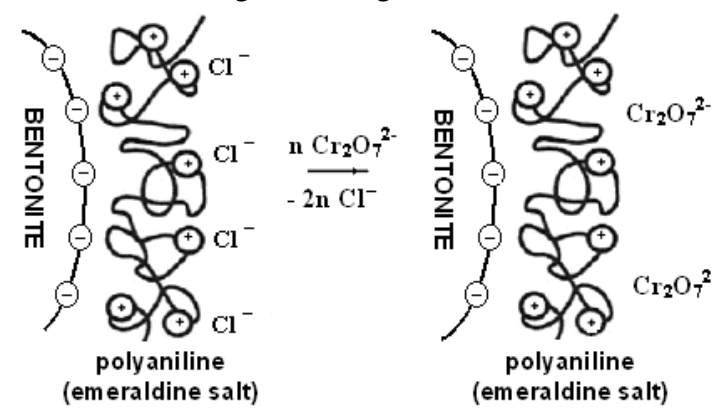

Fig. 8. Ion exchange mechanism of adsorption of ions

Emeraldine salt is partially converted into emeraldine base at $\mathrm{pH}$ more than 4 . The same adsorption mechanism we observed for other natural minerals in our previous works [11-13].

The results of kinetic characteristics of the obtained composite are shown in Fig. 9.

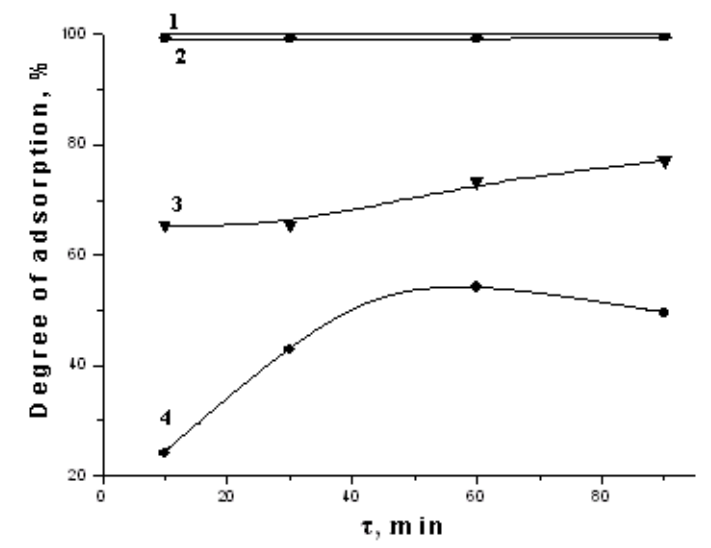

Fig. 9. Dependences of the degree of the adsorption of the anions of polyvalent metals upon the contact time on the composite bentonite immobilized by polyaniline: $1-\mathrm{Cr}(\mathrm{VI}) ; 2-\mathrm{W}(\mathrm{VI}) ; 3-\mathrm{Mo}(\mathrm{VI}) ; 4-\mathrm{V}(\mathrm{V})$

As it follows from this figure, in the case of the synthesized composite the equilibrium time for the adsorption of tungstate and chromate ions is reached quickly. For molybdate and vanadate ions the kinetic equilibrium is established gradually throughout 90 and 60 minutes respectively.

Adsorption isotherms were studied and compared to determine the adsorption capacity of the initial bentonite and the composite obtained with respect to $\mathrm{Cr}(\mathrm{VI})$, $\mathrm{Mo}(\mathrm{VI}), \mathrm{W}(\mathrm{VI})$ and $\mathrm{V}(\mathrm{V})$ anions. The results obtained are shown in Fig. 10, Fig. 11 and Table 3.
Table 3. The adsorption capacity of the obtained composite with respect to the investigated anions

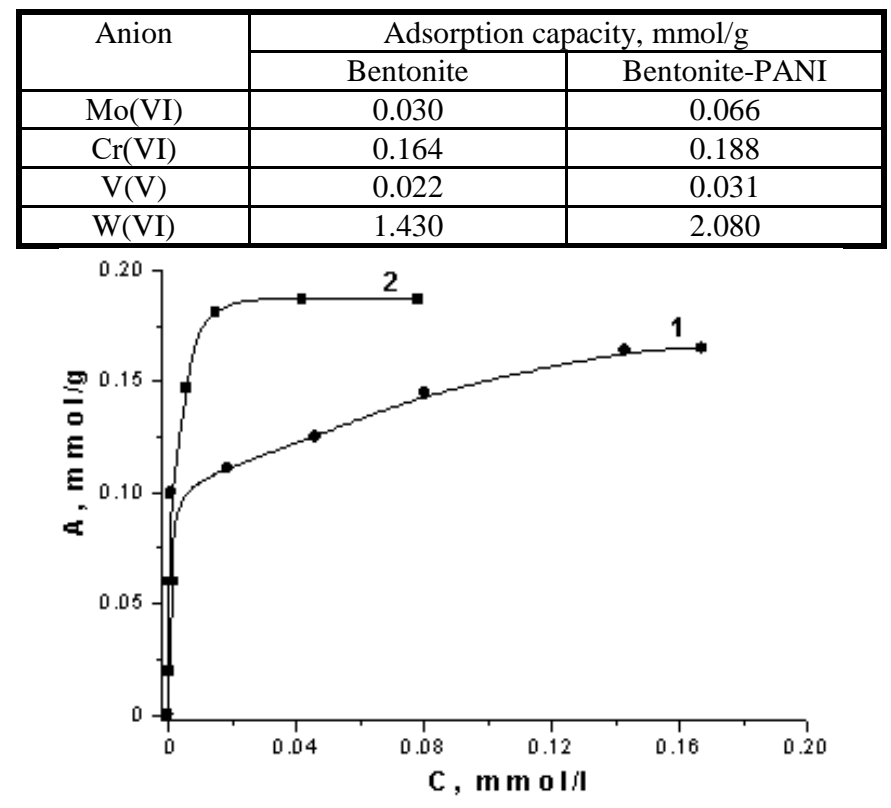

Fig. 10. Adsorption isotherms for $\mathrm{Cr}(\mathrm{VI})$ anions on bentonite (1) and bentonite immobilized by polyaniline (2) at $\mathrm{pH}=1.7$

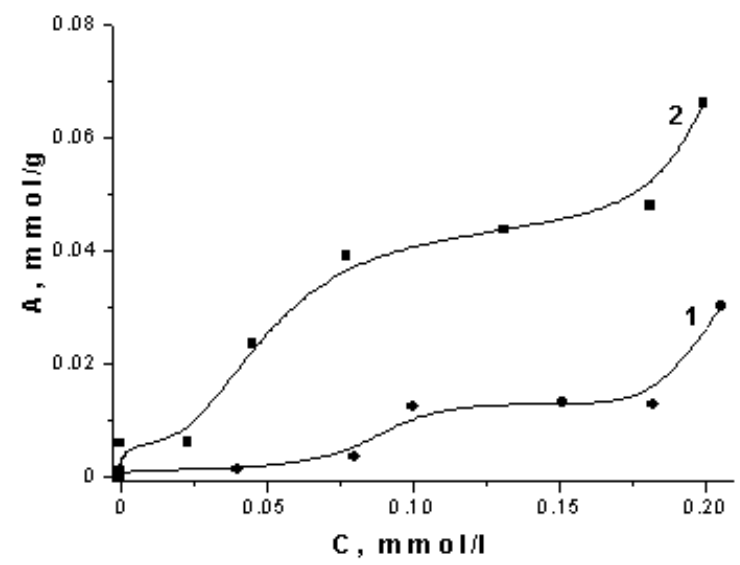

Fig. 11. Adsorption isotherms for Mo(VI) anions on bentonite (1) and bentonite immobilized by polyaniline (2) in distilled water

As follows from Table 3 and Fig. 10, the maximum adsorption capacity for $\mathrm{Cr}(\mathrm{VI})$ anions on the initial bentonite and the bentonite with immobilized polyaniline took place at $\mathrm{pH} 1.7$ and was 0.164 and $0.188 \mathrm{mmol} / \mathrm{g}$ respectively. However, the range of quantitative adsorption of $\mathrm{Cr}_{2} \mathrm{O}_{7}{ }^{2-}$ anions on the surface of composite is $0.01 \mathrm{mmol} / \mathrm{g}$ whereas quantitative adsorption on the initial bentonite is not observed for any of the investigated ions.

The isotherm of $\mathrm{Cr}(\mathrm{VI})$ ions can be referred to as the Langmuir isotherms of 2L-type. Similar shape of isotherm is observed for $\mathrm{V}(\mathrm{V})$ anions.

As indicated in Table 3, the modification of the surface of bentonite by polyaniline led to the increased adsorption with respect to $\mathrm{V}(\mathrm{V})$ ions from $0.022 \mathrm{mmol} / \mathrm{g}$ to $0.031 \mathrm{~mol} / \mathrm{g}$. Quantitative adsorption of $\mathrm{V}(\mathrm{V})$ anions was not observed for the composite bentonite-PANI.

As follows from Table 4 and Fig. 11, the maximum adsorption capacity for Mo(VI) anions increased from 0.03 and $0.066 \mathrm{mmol} / \mathrm{g}$. Quantitative adsorption of $\mathrm{Mo}(\mathrm{VI})$ 
anions was observed in the wide concentration range, namely up to $0.066 \mathrm{mmol} / \mathrm{g}$ on the obtained composite.

The isotherm of Mo(VI) (Fig. 11) ions is stepped and can be referred to as the Langmuir isotherms of 4L-type. This shape of isotherm can be explained by the presence of centers of crystallization of molybdate ions on the surface of composite which are converted into complex polymolybdate ions (for example $\left[\mathrm{Mo}_{6} \mathrm{O}_{21}\right]^{6-}$ and $\left[\mathrm{Mo}_{7} \mathrm{O}_{24}\right]^{6-}$ ) on long standing (isotherms conducted within 24 hours) [28-31]. Similar situation is observed for W(VI) anions.

All the isotherms (Fig. 10, Fig. 11) can be referred to as the Langmuir isotherms. This fact means that:

- the immobilized polyaniline is regularly distributed on the surface of the carrier and appears to be a very valuable property of the adsorbent;

- oxo anions of Cr(VI), Mo(VI), W(VI) and V(V) are on the surface of the adsorbent in the form of ionassociates [31].

It was established that the adsorption properties of the synthesized composite with respect to the studied oxo ions were worse than the adsorption properties of composite vermiculite-PANI [13], similar to the composite Sokyryntsyy clinoptilolite-PANI [12] and better than composites of polyaniline with Podilskyy saponite and Karelian shungite [11].

\section{CONCLUSIONS}

Polyaniline was in situ immobilized on natural mineral bentonite via oxidative polymerization of aniline. Anchorage of polyaniline on the surface of bentonite was confirmed by IR spectroscopy, diffuse reflectance electronic spectra (DRES) and thermogravimetric analysis.

It was established as a result of the modification of bentonite a surface area and an interlayer distance of mineral decrease and particles of bentonite transformed of irregular shape with different porosity on irregularly shaped particles of smaller size using low-temperature adsorption/desorption of nitrogen, X-ray spectroscopy and SEM.

It has been found that the bentonite, in situ immobilized with polyaniline, can show high adsorption activity as to $\mathrm{W}(\mathrm{VI})$ anions in the acidic, alkaline and neutral media; but with respect to $\mathrm{Cr}(\mathrm{VI})$ anions in the acidic medium only. Whereas adsorption of oxo anions of $\mathrm{V}(\mathrm{V})$ and $\mathrm{Mo}(\mathrm{VI})$ made up some $50 \%$ in the alkaline and neutral media respectively. Adsorption of ions occurs by ion exchange mechanism.

The maximum values of adsorption of $\mathrm{Cr}(\mathrm{VI})$, $\mathrm{Mo}(\mathrm{VI}), \mathrm{W}(\mathrm{VI})$ and $\mathrm{V}(\mathrm{V})$ anions on bentonite, in situ immobilized by polyaniline, was proved to occur within 24 hours in a static mode at periodic shaking.

It has been found that in situ immobilization of bentonite with polyaniline can lead to a twofold increase of the range of the adsorption capacity $\mathrm{MoO}_{4}{ }^{2-}$ anions, growth of the sorption capacity with respect to W(VI) anions, and good adsorption of micro quantities of $\mathrm{Cr}(\mathrm{VI})$ and $\mathrm{V}(\mathrm{V})$ anions.

It was determined that all investigated ions are regularly distributed on the surface of the adsorbent and molybdate and tungstate ions superimposed on the surface of composite forming complex polymolybdates or polytungstates respectively.

\section{REFERENCES}

1. Perepelytsya, O. Ecochemistry and Endoecology of Elements. Ekohim, Kyiv, 2004: pp. 3-736.

2. Epstein, S., Meydel, I., Nesterova, V., Minaev, V., MelikGaykazov., Ya. Industrial Wastewater Treatment Using Reagents Based on Peat, 2012: pp. 303-311// access mode: http://www.giab-online.ru/files/Data/2012/9/303311_Epshteyn_9_2012.pdf.

3. Amuda, O.S., Giwa, A.A., Bello, I.A. Removal of Heavy Metal from Industrial Wastewater Using Modified Activated Coconut Shell Carbon Biochemical Engineering Journal 36 2007: pp. 174-181.

4. Kongsricharoern, N., Polprasert, C. Electrochemical Precipitation of Chromium $\left(\mathrm{Cr}^{6+}\right)$ from an Electroplating Wastewater Water Science and Technology 31 1995: pp. 109-117.

5. Zhang, D., Wei, S., Kaila, C., Su, X., Wu, J., Karki, A.B., Young, D.P., Guo, Z. Carbon-Stabilized Iron Nanoparticles for Environmental Remediation Nanoscale 2 (6) 2010: pp. 917-919.

6. Polishchuk, L., Yanovskaya, E., Yanishpolskii, V., Tertykh, V., Sukhoi, K., Burmistr, M. Silica Gel with Immobilized Polyionenes of Adsorption to Mo(VI), Cr(VI), $\mathrm{W}(\mathrm{VI})$ and $\mathrm{V}(\mathrm{V})$-Containing Anions Russian Journal of Applied Chemistry 80 (9) 2007: pp. 1558-1561.

7. Tertykh, V., Polishchuk, L., Yanovska, E., Dadashev, A. Concentration of Anions by Silica Adsorbents with Immobilized Nitrogen-Containing Polymers Adsorption Science and Technology $26(1-2)$ 2008: pp. 59-68.

8. Dadashev, A., Yanovska, E., Tertykh, V. Application of Silica with Grafted Polyhexamethyleneguanidine in Concentration and Determination of Transition Metal Cations and Metal-Containing Anions Scientific Notes of NaUKMA 92 2009: pp. 23-27.

9. Dadashev, A., Tertykh, V., Yanovska, E., Yanova, K. Ion-Exchange Properties of Modified Silicas with Bound Amides of Polyhexamethyleneguanidine and Maleic or $o$ Phthalic Acids with Respect to Metal-Containing Anions Chemistry, Physics and Technology of Surface 4 (3) 2012: pp. 419-428.

10. Guo, J.Z., Gu, H., Guo, J., Wei, H., Zhang, X., Wei, S. Multifunctional Nanocomposites for Environmental Remediumtion Society of Plastics Engineers 2013: doi: 10.2417/spepro.004829.

11. Budnyak, T., Yanovska, E., Tertykh, V., Kichkiruk, O. Adsorption Properties of Natural Minerals with In Situ Immobilized Polyaniline Towards Anionic Forms of Mo(VI), W(VI), Cr(VI), As(V), V(V) and P(V) Problems of Chemistry and Chemical Technology Journal 5 2010: pp. $43-47$.

12. Budnyak, T., Yanovska, E., Tertykh, V., Voznyuk, V. Adsorption Properties of Composite Sokyrnytskyy Clinoptilolite-Polyaniline Towards Anions of Elements V and VI Groups of the Periodic System Reports of National Academy of Sciences of Ukraine Journal 3 2011: pp. $141-145$.

13. Ryabchenko, K., Yanovska, E., Tertykh, V., Kichkiruk, O., Sternik, D. Adsorption Properties of Vermiculite with In Situ Immobilized Polyaniline with Respect to $\mathrm{Cr}(\mathrm{VI}), \quad \mathrm{Mo}(\mathrm{VI}), \quad \mathrm{W}(\mathrm{VI}), \quad \mathrm{V}(\mathrm{V})$ and 
P(V) Anions Adsorption Science and Technology 32 (1) 2014: pp. 89-99.

14. Ryabchenko, K., Khutoryanska T., Yanovska, E., Ianovska M., Kichkiruk, O. Scientific Basis of the Regeneration of Chromium, Tungsten, Molybdenum and Vanadium Compounds from Waste Using Cellulose In Situ Immobilized by Polyniline Conference of Young Scientists 29-30 November 2012 «Colloid-Chemical Problems of Environmental Protection and Water Quality Control»: pp. $73-74$.

15. Reid-Soukup, D.A., Ulery, A.L. Solid Mineralogy with Environmental Application. Madison, Wicconsin, 2002: pp. $467-499$.

16. Zhao, D.L., Feng, S.J., Chen, C.L., Chen, S.H., Xu, D., Wang, X.K. Adsorption of Thorium(IV) on MX-80 Bentonite: Effect of $\mathrm{pH}$, Ionic Strength and Temperature Applied Clay Science 41 2008: pp. 17-23.

17. Qian, L., Qin-Yan, Y., Yuan, S., Bao-Yu, G., Jing, L. Two-Step Kinetic Study on the Adsorption and Desorption of Reactive Dyes at Cationic Polymer/Bentonite Journal of Hazardous Materials 165 2009: pp. 1170-1178.

18. Safa, Ö.A., Adnan, Ö. Adsorption of Acid Dyes from Aqueous Solutions onto Acid-Activated Bentonite Journal of Colloid and Interface Science 276 2004: pp. 39-46.

19. Aboutanos, V., Barisci, J.N., Kane-Maguire, L.A.P., Wallace, G.G. Electrochemical Preparation of Chiral Polyaniline Nanocomposites Synthetic Metals 106 1999: pp. 89-95.

20. Trchov, M., Stejskal, J. Polyaniline: The Infrared Spectroscopy of Conducting Polymer Nanotubes (IUPAC Technical Report) Pure and Applied Chemistry 83 (10) 2011: pp. $1803-1817$.

21. Nakanisi, K. IR Spectra and Structure of Organic Compounds. Mir, Moscow, 1965: pp. 3-216.
22. Tolstenko D., Vyatkina O. Comparative Analysis of IonExchange Properties of Bentonites, Used in Vinemaking Scientific Notes of Taurida V. Vernadsky National University 24 (63) 2011: pp. 185-191.

23. Dimitriev O. Suppression of the Emeraldine Base to Emeraldine Salt Transition in Ultra-thon of Polyaniline Synthetic Metals 122 2002: pp. 315-319.

24. Bergaya, F., Theng, B.K.G., Lagaly, G., (Eds.). Handbook of Clay. Elsevier, Amsterdam, 2006: pp. 3-547.

25. Sternik, D., Majdan M., Deryło-Marczewska, A., Żukociński, G., Gładysz-Płaska, A., Gun'ko, V. Influence of Basic Red 1 Dye Adsorption on Thermal Stability of NaClinoptilolite and Na-Bentonite Journal Thermal Analysis and Calorimetry 103 2011: pp. 607-615.

26. Barrett, E.P., Joyner, L.G., Halenda, P.P. The Determination of Pore Volume and Area Distributions in Porous Substances. I. Computations from Nitrogen Isotherms Journal of the American Chemical Society 73 1951: pp. 373-380.

27. Ramírez-Valle, V., Lerf, A., Wagne, F.E., Poyato, J., Pérez-Rodríguez, J.L. Thermal Study of Polypyrrole Complexes with Vermiculites of Different Layer Charge Journal of Thermal Analysis and Calorimetry 92 2008: pp. $43-51$.

28. Marchenko, Z. Photometric Determination of Elements. Mir, Moscow, 1971: pp. 3-501.

29. Busev, A., Ivanov, V., Sokolova, T. Analytical Chemistry of Wolfram. Nauka, Moscow, 1976: pp. 3-240.

30. Muzgin, V., Khalezin, L., Zolotavin, V., Bezrukov, I. Analytical Chemistry of Vanadium. Nauka, Moscow, 1981: pp. 3-215.

31. Parfitt, G., Rochester, C. Adsorption from Solution at the Solid/Liquid Interface. Mir, Moscow, 1986: pp. 3-488. 